\title{
PENDAMPINGAN BELAJAR BAHASA INGGRIS DASAR BERBANTUAN METODE MONTESSORI UNTUK SISWA SD DI DESA DEMULIH PADA MASA PANDEMI COVID-19
}

\author{
L.M.D Wedayanthi'), P.A. Adiwijaya' ${ }^{1)}$, M.A. Purnami') \\ 1)Program Studi Pendidikan Bahasa Inggris, FIP, ITP Markandeya Bali, Bangli, Bali, Indonesia \\ Corresponding author : L.M.D Wedayanthi \\ Email: wedawid06@gmail.com
}

Diterima 09 Agustus 2021, Direvisi 30 Agustus 2021, Diterima 30 Agustus 2021

\begin{abstract}
ABSTRAK
Pelajaran Bahasa Inggris dasar untuk siswa SD di desa Demulih merupakan pengabdian kepada masyarakat yang diselenggarakan pada masa Pandemi Covid-19. Mata pelajaran Bahasa Inggris sejatinya hanya merupakan pelajaran muatan lokal yang dimulai dari kelas $5 \mathrm{SD}$, yang hanya diberikan di beberapa sekolah. Tujuan dari pengabdian ini adalah untuk mengenalkan bahasa Inggris dasar kepada siswa SD, sebagai upaya membantu mereka untuk menghadapi komunikasi global dan persiapan menghadapi masa transisi ke sekolah menengah. Penyampaian Pelajaran Bahasa Inggris anak menggunakan metode Montessori yang merupakan metode pembelajaran yang memanfaatkan fasilitas dan media di lingkungan sekitar siswa. Siswa SD yang digunakan adalah siswa SD di desa Demulih, Kecamatan Susut, Kabupaten Bangli. Kegiatan PKM dilaksanakan selama 8 kali pertemuan dengan 4 tahap untuk setiap sesinya. Keberhasilan kegiatan ini dapat terlihat dari semangat siswa SD di desa Demulih yang selalu hadir dan selalu bertambah setiap pertemuannya, serta keaktifan mereka dalam berpartisipasi dalam kegiatan pembelajaran. Secara keseluruhan, pendampingan belajar Bahasa Inggris dasar mampu menumbuhkan dan membantu siswa SD dalam belajar Bahasa Inggris dasar di masa pandemi Covid-19.
\end{abstract}

Kata Kunci: bahasa Inggris dasar; montessori; pandemi covid-19.

\begin{abstract}
Basic English lesson for elementary school students in Demulih village are community service held during the Covid-19 pandemic. English subject are actually only role as local content lessons which is thought from grade 5 elementary school, which are only given in some schools. The main purposes of this community service are to introduce Basic English to elementary students, as an effort to help them face global communication and preparation for the transition to high school period. The way to deliver of English lesson to children uses Montessori method which is a learning method utilizes facilities and media in students' environment. The elementary school students which is a object in this research were the students in Demulih Village, Susut District, Bangli Regency. This community service activity was done in 8 meetings, 4 stages for each meeting. The success indicators of this activity are the students always present and this increase from time to time in each meeting, as well as their participation in the learning activities. Overall, Basic Engliss Learning Assistance is able to grow and assist elementary students in learning basic English during the Covid-19 Pandemic.
\end{abstract}

Keywords: basic english; montessori; covid-19 pandemic.

\section{PENDAHULUAN}

Pengenalan Bahasa Inggris Dasar bagi siswa Sekolah Dasar masih sebagai mata pelajaran muatan lokal atau sebagai mata pelajaran tambahan. Beberapa orang tua yang menginginkan anaknya dipersiapkan dengan baik, memberikan peluang untuk mengikuti kursus bahasa Inggris. Keberadaan Bahasa Inggris di Sekolah Dasar disesuaikan dengan kebutuhan pada tingkat satuan Pendidikan. Sehingga untuk setiap sekolah pada jenjang Pendidikan dasar dapat memilih dan menentukan apakah akan memasukkan mata pelajaran bahasa Inggris atau mata pelajaran lain seperti Bahasa Daerah masing-masing. Meskipun mengalami kemunduran dalam status menjadi mata pelajaran tambahan, sesungguhnya mata pelajaran Bahasa Inggris memiliki peran strategis dalam penyiapan siswa sejak dini dalam komunikasi internasional. Perkembangan dunia internasional tidak lagi dibatasi pada sekat tebal yang membatasi komunikasi antar negara. Contoh yang mudah ditemui adalah sosial media yang 
membebaskan siapa saja bertemu secara virtual dengan masyarakat internasional dari berbagai negara. Memperkenalkan bahasa Inggris dasar kepada siswa SD juga merupakan Langkah yang tepat, hal ini didukung oleh pendapat Dunn (1983) dalam (Listia, 2008) bahwa pembelajar muda sangat mudah meningkatkan kemampuan berbahasa mereka melalui permainan yang tepat untuk usia mereka. Akan tetapi permainan yang cocok untuk usia mereka akan menjadi lebih tepat.

Melihat pentingnya pengenalan bahasa Inggris dasar pada anak usia sekolah dasar, maka proses mengenalanpun harus menggunakan metode yang menyenangkan sehingga tidak menjadi momok yang menyulitkan untuk memahami dan mengpalikasikan bahasa Inggris di kemudian hari. Untuk mempermudah pengenalan bahasa Inggris dasar, metode Montessori menawarkan solusi berupa Pendidikan terpadu yang bisa diterapkan dirumah secara mandiri atau terbimbing oleh siswa dan guru dengan memanfaatkan kondisi dan fasilitas yang ada disekitar lingkungan belajar. Montessori adalah metode yang dikembangkan pertama kali oleh Dr. Maria Montessori,seorang psikolog Italia, memulai karirnya sebagai seorang pendidik pada tahun 1898, sekolahnya Bernama Casa dei Bambini (Larson, 2010). Metode ini merupakan suatu metode yang dipersiapkan oleh Dr. Maria Montessori sebagai suatu metode Pendidikan untuk anak-anak yang didasarkan pada teori perkembangan anak. Hal ini didukung pula oleh Larson ( 2010) yang menjelaskan bahwa Montessori memberikan kesempatan bagi anak-anak untuk bebas dalam belajar, menentukan topik serta material yang akan dipergunakan.

Terdapat lima aspek yang merupakan prinsip dalam metode Pendidikan Montessori. Aspekaspek tersebut adalah; 1) pentingnya kebebasa, 2) struktur dan keteraturan, 3) realistis dan alami, 4) keindahan dan nuansa, dan 5) alat bermain Montessori atau metia pembelajaran Montessori (Adisti, 2016). Menurut Montessori (Rahmawati, 2017) mengatakan bahwa empat ciri khusus metode pembelajaran Montessori yaitu menarik, bergradasi, auto-correction, auto-education, dan kontekstual. Melihat dari esensi dari pembelajaran menggunakan metode Montesori, maka pantaslah dipasangkan dengan pendampingan belajar bahasa inggris dasar anak usia SD di masa Pandemi, melihat fasilitas yang bisa digunakan terbatas dan suasana informal terbiasa akan terjadi. Hal ini didukung oleh tulisan (Hainstok, 1999) menurutnya, suatu fase kehidupan di awal sangat berpengaruh terhadap fase kehidupan selanjutnya artinya pengalaman-pengalaman yang dialami oleh anak di awal kehidupannya sangat berpengaruh terhadap Pendidikan kedewasaanya kemudian. Metode Montessori membantu perkembangan anak dengan esensi metode yaitu; (1) The Absorbent Mind yang membuat anak mudah menyerap pembelajaran yang membentuk pikiran yang mengasimilasi lingkungan fisik dan sosial, (2) The Concious Mind, yang membuat mereka menyadari apa yang ingin dan akan mereka pelajari atau mereka belajar dengan kebebasan, (3) The Sensitive Periods, yang merupakan perpaduan mereka dalam memaksimalkan fungsi panca indera mereka dalam belajar, (4) Children Want to Learn, yaitu memunculkan kemandirian anak yang muncul dari rangsangan belajar, dan (5) Learning Through Play, memanfaatkan bermain menjadi media pembelajaran (Morrison, 2012).

Untuk itu maka perlu diadakan pendampingan belajar bahasa Inggris ini bertujuan untuk membantu anak usia SD di desa Demulih, kecamatan Susut, Bangli dalam mengenal bahasa Inggris dasar. Melalui observasi dan interview dengan siswa sekolah dasar di desa demulih dapat disimpulkan mereka belum mendapatkan pelajaran bahasa inggris secara utuh dalam pelajaran namun hanya beberapa kali di mata pelajaran muatan lokal serta beberapa anak mempelajari dari kursus bahasa Inggris di luar sekolah.

Berdasarkan paparan di atas, maka penulis berkeinginan untuk melaksanakan kegiatan PKM (Pengabdian Kepada Masyarakat) pendampingan belajar bahasa Inggris dasar anak usia SD di Desa Demulih yang menggunakan metode Montessori sebagai metode pengajaran agar lebih beradaptasi dengan keadaan pandemi covid19. Kegiatan tersebut dilaksanakan di wilayah banjar desa Demulih dengan mematuhi Protokol Kesehatan yang ketat. Pengabdian ini diharapkan bisa membantu anak usia SD untuk mengenal bahasa Inggris dasar anak, sebagai persiapan mereka dalam melangkah ke Pendidikan lebih lanjut atau dalam komunikasi insidental mereka dalam menggunakan bahasa Inggris.

\section{METODE}

Pengabdian ini dilaksanakan di Desa Demulih, Kecamatan Susut, Kabupaten Bangli, Bali. Des aini berjarak 10 menit dari pusat kota Bangli, dan merupakan desa dengan penduduk yang padat karena terdiri dari beberapa banjar. Dalam prosesnya, pengabdian ini dibantu oleh mahasiswa KKN ITP Markandeya Bali yang berjumlah 6 orang. Mahasiswa tersebut membantu dalam pengumpulan data, 
penyebaran kuesioner serta membantu dalam pendampingan pengajaran untuk mendampingi siswa dalam mengikuti prosesnya. Jumlah siswa yang mengikuti kegiatan pengabdian ini adalah sejumlah 18 orang, yang terdiri dari kelas 5 SD dan beberapa diantaranya kelas 4 SD. Untuk setiap sesinya dilaksankan selama 2 jam. Kegiatan pengabdian ini menggunakan metode Montessori dalam latihannya, ceramah dalam menjelaskan materi, serta diskusi dalam mengevaluasi kegiatan. Pelaksanaan pengabdian ini selama 4 minggu, dengan dua kali pertemuan untuk setiap minggunya, sehingga total pertemuan selama pengabdiannya adalah delapan sesi. Tahapan dalam setiap sesi adalah membangun motivasi belajar dengan cara bernyanyi dan bergerak bersama, pengenalan materi dengan menggunakan media seperti flashcard atau dengan benda langsung, bermain dengan metode Montessori berdasarkan materi, pendalaman materi dengan menggunkan metode Montessori dan sesi evaluasi berupa soal-soal yang dikemas dengan evaluasi metode Montessori.

\section{HASIL DAN PEMBAHASAN}

Pengabdian pendampingan belajar bahasa Inggris dasar menggunakan metode Montessori pada masa Pandemi covid-19 untuk anak SD berlokasi di desa Demulih berjalan dengan lancar sesuai dengan perencanaan. Pengenalan bahasa Inggris dasar untuk siswa SD sangatlah penting, hal ini didukung oleh pendapat (Aedi, 2016) mengatakan bahwa di era globalisasi dan instant sekarang ini, anak dididik mulai dari usia SD bahkan TK sudah dituntut bersaing dalam mata pelajaran bahasa Inggris. Meskipun terdapat sedikit kendala dengan pemberlakuan PPKM (Pemberlakuan Pembatasan Kegiatan Masyarakat) yang dilaksanakan awal Juli, namun bisa teratasi dengan memadukan dengan menggunakan pembelajaran dengan group What's App.(WAG).

Pengabdian Kepada Masyarakat ini, dilaksanakan di Desa Demulih, Kecamatan Susut, Kabupaten Bangli. Kegiatan terlaksana selama 8 kali pertemuan selama 1 bulan, setiap minggunya diadakan 2 kali pertemuan. Jumlah siswa SD yang mengikuti kegiatan PKM ini adalah 18 siswa, dengan jenjang sekolah kelas 4-5 SD. Waktu pengadaan PKM ini berkisar mulai pukul 14.00 sampai dengan pukul 16.00. Rentangan waktu yang dipergunakan adalah dua jam, hal ini dikarenakan menggunakan metode Montessori, sehingga mereka tidak merasa jenuh dalam belajar bahasa Inggris dasar.
Adapun tahapan pendampingan belajar bahasa Inggris dasar yang dilaksanakan di desa Demulih melalui 4 tahapan untuk setiap pertemuannya. Tahapan pertamanya adalah di awal memulai pelajaran, dimulai dengan memotivasi siswa dengan cara bernyanyi, menari, atau permainan yang berhubungan dengan materi yang akan disampaikan atau materi yang telah dipelajari. Kegiatan tersebut dapat dilihat dari gambar dibawah:
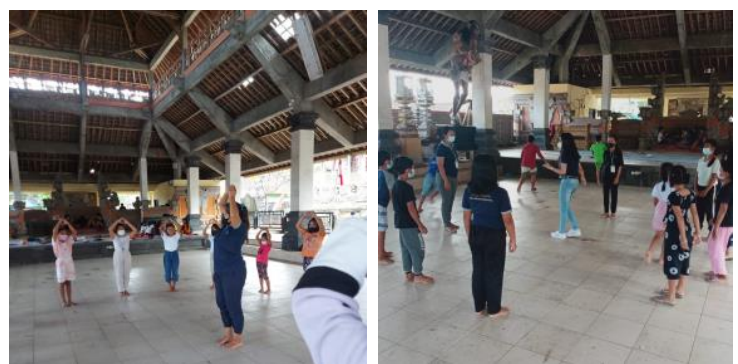

Gambar 1. Kegiatan Motivasi/ Bernyanyi dan Menari.

Tahapan kedua merupakan pengenalan materi yang sedikit menggunakan metode ceramah untuk memberi pengarahan, kemudian pengenalan materi dilaksanakan dengan menggunakan metode Montessori, sehingga mereka bisa mengenali sendiri dan menggunakan secara langsung. Seperti bisa dilihat dari gambar 2 saat penulis memberikan pengenalan materi.

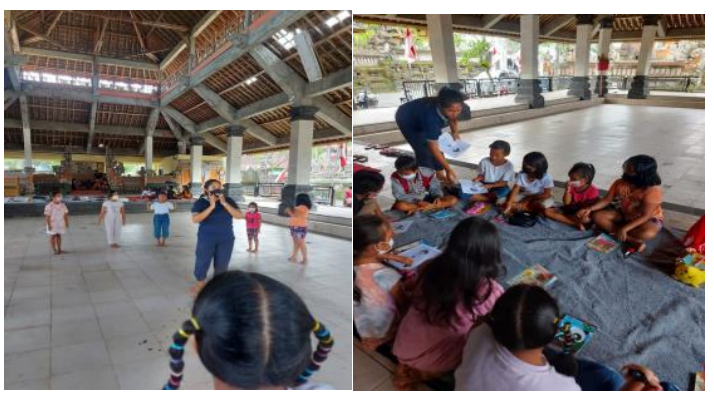

Gambar 2. Pengenalan materi tentang human body secara langsung dan gambar

Tahapan ketiga yaitu pendalaman materi dengan cara praktek langsung dengan menggunakan metode Montessori yaitu menggunakan media sekitar, permainan yang dimodifikasi, gerakkan, dan tidak berpatokan dengan kertas atau pulpen. Pada tahapan ketiga diterapkan bagian-bagian dari Montessori, yaitu; pratical life, sensorial area, language area, math, dan culture. Untuk setiap area tersebut diadakan kegiatan mandiri atau perpaduan dari 2 atau 3 area sekaligus. Dalam gambar 3 bisa dilihat bagaimana permainan dipergunakan dalam mengajarkan mereka tentang materi yang diajarkan. 


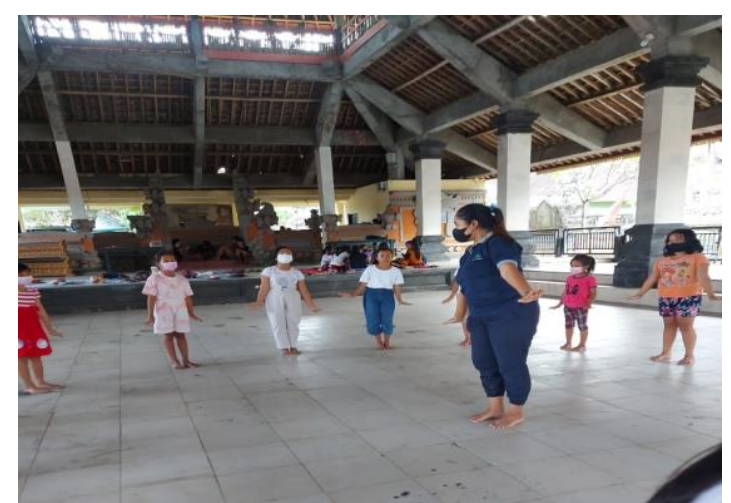

Gambar 3. Permainan menebak bagian tubuh, menggerakkan, menyentuh, dan menyebutkan benda yang berhubungan dengan bagian tubuh tersebut.

Tahapan terakhir adalah evaluasi, dalam tahapan ini penulis memberikan evaluasi yang bukan merupakan evaluasi pada umumnya yang mengerjakan soal di atas kertas, namun dengan kegiatan berupa projek atau penampilan yang membuat mereka tidak terpaku dengan kegiatan menulis, atau seperti kegiatan di sekolah pada umumnya. Evaluasi yang dilaksanakan dengan membiarkan mereka secara bebas mengekspresikan gambar yang dipotong dan ditempel seperti pada kegiatan di gambar 4. Nilai akhir yang dilihat adalah bagaimana mereka secara tepat dan kreatif mencocokkan gambar satu dengan yang lainnya serta dijelaskan oleh daya kreasi mereka dengan warna dan bentuk.

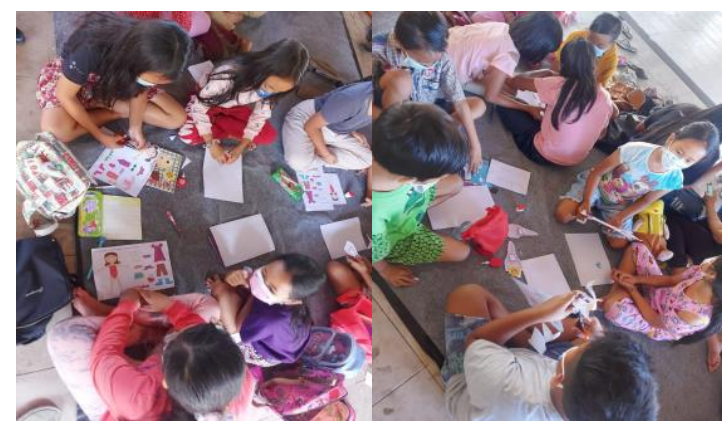

Gambar 4. Evaluasi dengan menggunakan kegiatan Potong dan Tempel Bagian tubuh dengan aksesoris yang dipasangkan secara bebas oleh anak.

Dalam setiap tahapan siswa akan dituntut untuk bergerak dan bermain dengan tidak membebani siswa dengan beban tugas-tugas atau pengerjaan soal-soal. Hal ini diharapkan akan memancing rasa ingin tahu siswa untuk lebih mempelajari bahasa Inggris dasar secara mandiri setelah kegiatan PKM ini usai.

Dalam pengabdian ini, bisa dikatakan berhasil dengan indikator keberhasilan kegiatan pendampingan belajar bahasa Inggris dasar siswa SD di masa pandemic covid-19 dapat dilihat dari jumlah siswa yang mengikuti kegiatan pendampingan belajar ini konsisten dari awal sampai akhir. Dalam proses belajar juga bisa dilihat antusias siswa dalam bermain kata, atau memasangkan, tebak-tebakan, dan juga kegiatan memotong dan menempelkan. Dalam kuesioner yang disebar pada akhir kegiatan juga bisa diketahui bagaimana mereka menikmati proses belajar yang dimodifikasi dengan menggunakan metode Montessori, dengan bermain dan belajar bisa memudahkan mereka mengerti akan kosa kata dalam bahasa Inggris. Keaktifan mereka dikelas juga merupakan indikator sukses dari kegiatan PKM ini, dikarenakan mereka selalu berani untuk bertanya dan mengekplorasi diri dapat dilihat dari kebebasan dan kemandirian mereka dalam memasangkan media ajar.

\section{SIMPULAN DAN SARAN}

Dari pembahasan hasil di atas, dapat disimpulkan beberapa hal yaitu; 1. Siswa tertarik mempelajari bahasa Inggris dasar dengan menggunakan metode Montessori, 2. Menggunakan metode Montessori membuat siswa lebih mudah dan nyaman mempelajari bahasa Inggris dasar, 3. Pendampingan belajar bahasa Inggris dasar dengan menggunakan metode Montessori membantu anak lebih mudah dan gampang dalam mempelajari bahasa Inggris, dan 4. Kegiatan pendampingan belajar pada masa pandemic sangat diperlukan oleh anak usia SD. Berdasarkan hasil-hasil tersebut dapat diketahui kemauan mereka untuk mempelajari bahasa Inggris dasar, serta mengenalkan proses belajar baru yaitu dengan metode Montessori yang membantu mereka belajar mengenal bahasa Inggris dasar dengan memanfaatkan media yang disediakan lingkungan sekitar siswa. Antusias siswa dalam mengikuti kegiatan PKM merupakan suatu indikasi ketertarikan mereka dalam Bahasa Inggris meskipun beberapa diantara mereka baru pertama kali mempelajari dan mengenal kosa kata bahasa Inggris. Oleh karena itu, kegiatan pendampingan belajar Bahasa Inggris dasar perlu dilaksanakan secara berkesinambungan

\section{UCAPAN TERIMAKASIH}

Rasa syukur dan terima kasih sebesarbesarnya kegiatan PKM ini tuntas dengan bantuan banyak pihak dalam mensukseskan kegiatan ini. Terutama mahasiswa KKN ITP Markandeya Bali tahun 2021 yang telah mengumpulkan anak dan membantu memfasilitasi anak-anak dalam belajar. Serta yang utama adalah siswa SD di desa Demulih yang meluangkan waktu dan keceriaannya 
dalam mengikuti kegiatan Pendampingan belajar ini.

\section{DAFTAR RUJUKAN}

Adisti, A. R. (2016). Perpaduan Konsep Islam dengan Metode Montessori dalam Membangun Karakter Anak. MUDARRISA: Jurnal Kajian Pendidikan Islam, 8(1), 61-88. https://doi.org/10.18326/mdr.v8i1.61-88

Aedi, N. (2016). Dasar-Dasar Manajemen Pedidikan. Gosyen Publishing.

Hainstok, E. G. (1999). Metode Pengajaran Montessori untuk Anak Pra Sekolah Panduan Praktis dan Effisien Mudah Dipelajari untuk Mendidik Anak. http://opac.iainkediri.ac.id/opac/index.php $? p=$ show_detail\&id $=2796$

Larson, H. E. I. K. E. (2010). The Montessori Method: Educating Children for a Lifetime of Learning and Happiness. Objective Standard: A Journal Of Culture \& Politics, 5(2), 41.

Listia, R. (2008). Kendala Pengajaran bahasa inggris di sekolah dasar. National Seminar Proceeding, 060, 468-475.

Morrison, G. S. (2012). Dasar-Dasar Pendidikan Anak Usia Dini. Indeks, Jakarta.

Rahmawati, A. (2017). Pengembangan Media Pembelajaran IPA SD Materi Penggolongan Hewan Berdasarkan Penutup Tubuhnya Berbasis Metode Montessori. Skripsi. 